DOI:

\title{
SEVEN FREQUENT MODELS IN BIBLICAL PHRASEOLOGY OF MODERN ENGLISH
}

\author{
Tatiana Fedulenkova \\ Doctor of Philological Sciences, Professor \\ Vladimir State University named after the Stoletov brothers \\ (Vladimir, Russia) \\ e-mail: fedulenkova@list.ru \\ Zoia Adamia \\ Doctor of Philology, Professor \\ Institute of Russian Language and Literature \\ at Tskhum-Abkhazian Academy of Sciences \\ (Tbilisi, Georgia) \\ e-mail: a.zoia777@gmail.com
}

\begin{abstract}
As a linguistic sign, any phraseological unit (PU) is a bilateral substance, that is, it has its own form and its own meaning. Now, when there is a general rush to the study of meaning in the linguistic sign — and from time to time irrespective of its form, - it is extremely important to draw the attention of linguists to the necessity of structural studies in the field of phraseology. Bearing in mind A. V. Kunin's statement, we maintain that it is impossible to study the meaning of the phraseological unit without studying its form. And it takes place because the form of the phraseological unit is meaningful in itself, presenting the inner-form of the PU. The form of the phraseological unit contains the so-called prototypical meaning and has the zero level of abstraction.

Consequently, the paper is targeted at the structural studies of the chosen phraseological space, namely, at the detailed analysis of componential structure of phraseological units of biblical origin in Modern English, at finding out the number of components in the phraseological unit and at drawing the sequence of components of the phraseological unit. To achieve the aims, a set of modern methods of research in the field of phraseology is employed, namely: the method of phraseological identification, the method of componential analysis, the method of phraseological description and the method of phraseological modelling. As additional methods of the research, a set of non-paradigmal methods and techniques of linguistics is employed, including a descriptive method with its procedures.

The research results in differentiation and description a set of most frequent structural-grammatical models embracing Modern English phraseology of biblical origin which is considered to be perspective for further cross-cultural as well as comparative studies of phraseological units and their systems in different languages.
\end{abstract}

Key Words: Modern English phraseology, phraseological units, biblical origin, structural-grammatical models

\section{СЕМЬ РАСПРОСТРАНЕННЫХ МОДЕЛЕЙ В БИБЛЕЙСКОЙ ФРАЗЕОЛОГИИ СОВРЕМЕННОГО АНГЛИЙСКОГО ЯЗЫКА}

\author{
Т. Н. Федуленкова \\ Доктор филологических наук, профессор \\ (Владимир, Россия) \\ e-mail: fedulenkova@list.ru \\ Зоя Адамия \\ Доктор филологии, профессор \\ Институт русского языка и литературы \\ Цхум-Абхазская академия наук \\ (Тбилиси, Грузия) \\ e-mail: a.zoia777@gmail.com
}

Владимирский государственный университет имени А.Г. и Н.Г. Столетовых

\begin{abstract}
Аннотация. Как лингвистический знак, любая фразеологическая единица является двусторонней субстанцией, то есть имеет свою форму и собственный смысл. Сейчас, когда наблюдается общее стремление к изучению смысла в лингвистическом знаке, крайне важно обратить внимание лингвистов на необходимость структурных исследований в области фразеологии. Принимая во внимание заявление А. В. Кунина, мы утверждаем, что невозможно изучить значение фразеологической единицы без изучения её формы. Это происходит потому, что форма фразеологической единицы сама по себе значима, представляя внутреннюю форму ФЕ, которая содержит так называемое прототипное значение и имеет нулевой уровень абстракции. Статья нацелена на структурные исследования избранного фразеологического пространства - на детальный анализ компонентной структуры фразеологических единиц библейского происхождения в современном английском языке, на выяснение количества компонентов в фразеологической единице и на выстраивание частых последовательностей компонентов фразеологической единицы. Для достижения поставленных целей используется комплекс современных
\end{abstract}


методов исследования в области фразеологии: метод фразеологической идентификации, метод компонентного анализа, метод фразеологического описания и метод фразеологического моделирования. В качестве дополнительных методов исследования используется ряд непарадигмальных методов и технологий лингвистики, включая описательный метод с его процедурами.

Результатом исследования является дифференциация и описание набора наиболее часто встречающихся структурнограмматических моделей, охватывающих современную английскую фразеологию библейского происхождения, что считается перспективным для дальнейших межкультурных, а также сравнительных исследований фразеологических единиц и их систем в разных языках.

Ключевье слова: современная английская фразеология, фразеологические единицы, библейское происхождение, структурно-грамматические модели

INTRODUCTION. The relevance of linguistic and cultural researches in the field of phraseology of biblical origin is maintained by the attention of modern linguists to the problems in the studies of the structure and meaning of biblical phraseological units (Adamia 2019: 25-26).

In the introduction to the monograph Idioms and Idiomaticity Chitra Fernando (Fernando 1996: 1) suggests a working definition of the idiom, which reads as follows: "Idioms, or conventional multiword expressions, often but not always non-literal, are hardly marginal in English, though they have been relatively neglected in lexical studies of the language." The paper presented is targeted to oppose that neglect and to draw the readers' and learners' attention to the abundance of nominative-communicative biblical phraseological units that function in Modern English and to the variety of their componential structure.

METHODS OF RESEARCH.The theoretical foundation of the paper is the conception of the phraseological unit and the method of phraseological identification with its general rules of the procedure, initiated by professor Aleksander V. Kunin (Kunin 1970: 37-48). To define the semantic role of the leading component in the formation of the meaning of the phraseological unit as a whole, the method of componential analysis, based on dictionary definitions, is used. To single out different classes of phraseological units and different types of dependence of their components, to analyze their morphological, lexical and syntactical peculiarities, the methods of phraseological analysis and description are used (Kunin 1996: 43). To analyze and distinguish structural models in verbal biblical phraseology, the method of phraseological modeling suggested by some paternal linguists is used (Mokienko 1976: 5; Fedulenkova 2006: 36). As additional methods of the research, a set of non-paradigmal methods and techniques of linguistics is employed, including a descriptive method with its procedures (Komarova 2013: 564).

DATA AND ANALYSIS.The data base for structural analysis embraces about 500 English phraseological units of biblical origin extracted from The Holy Bible (1991), monolingual and bilingual dictionaries and taken from real-life communication such as letters, advertisements, messages, notices, etc.

Having studied and analyzed the given bulk of phraseological units, we may state that the most widely spread nominal-communicative biblical idioms are those having two, three and four notional components. Their structuralgrammatical models are as follows:

Model 1. $\mathbf{V}+(\mathbf{d})+\mathbf{N}$

It is a two-component non-prepositional structural-grammatical model with the constant/-variant/ dependence of components (Kunin 1970: 62): to take thought [Matthew VI, 31], to darken council [Job XXXVIII, 2], to cumber the ground [Luke XIII, 7], to spoil the Egyptians [Exodus XII, 36], to remove mountains [Corinthians XIII, 7], etc. The relevance of phraseological units having the constant dependence of components and embraced by this structuralgrammatical model is confirmed by their modern contextual use, e.g.:

$<\ldots>$ image of fire and light clarifying the sight/understanding and consuming the whole being is left behind in a series of more abstract metaphors which relate to its dynamic quality drawing men to its source. The style is emotive but the intellectual understanding informing it has an astringent clarity which is very moving. It points to truth which has become wisdom born of experience: This is Rolle's version of 1 Corinthians 13:2: And if I should have prophecy and should know all mysteries, and all knowledge, and if I should have all faith, so that I could remove mountains, and have not charity, I am nothing. But he is more immediate in his evocation of the reality of a power that activates the potential efficacy in all areas of human endeavour and experience and runs counter to death. He creates a sense of a primal energy suffusing man as the sun does the air and fire a coal (10.110.56-72) and in his writing he tries to bridge the gap between intellectual acknowledgement of such a truth and experience of its reality. In only one manuscript is the $<\ldots>$. (BNC // English medieval mystics: games of faith. Glasscoe, Marion. Harlow: Longman Group UK Ltd, 1993, pp. 1-159. 1239 s-units.).

The given structural-grammatical model often allows variability of the verbal component: to bear/ carry the cross [Matthew X, 38; XVI, 24], to act/ play the fool [I Samuel XXVI, 21]. It has also a tendency to appear in discourse as a result of the reduction of the number of components in the phraseological unit, thus giving birth to a quantitative, or reduced, phraseological variant (Fedulenkova 2003: 14): to touch the ark (of the covenant) [2 Samuel VI, 6], to curse the day (one was born) [Job III, 1-3], etc. Numerous confirmations of the cut variant may be found in modern fiction:

$<\ldots>$ last visiting galley off the shore. 'Duart!' he said steadily. 'I have to thank you. Without your support I'd never have been accepted.' Eachuinn Odhar did not look up at his tall son. 'Never thank me,' he husked, for the three days had been hard on his injured throat. 'If there had been another - any other - I would have backed him, not you. 'Now he looked up, and Lachlan was hard put to it to meet the bitter glare.' I curse the day I got you. I curse myself for not strangling you in your cradle. And I set my curse on you if ever again you betray the clan. May God's punishment 
be a thousand times worse on you than the harm that you have done to Hector.' Lachlan's hand fell from his father's arm. Fury at the rejection welled up in him, but he forced it down. The old man was upset, but he'd soon change when he saw how well <... >. (BNC// Quest for a babe. Hendry, Frances Mary. Edinburgh: Canongate Pub. Ltd, 1990, pp. 43141. 3543 s-units.).

Model 2. V + Prep + (d) $+\mathbf{N}$

It is a two-component prepositional structural-grammatical model with the constant/-variant/ dependence of components (Kunin 1970: 62): to walk in darkness [John XII, 35], to kick against the pricks [Acts IX, 5; XXVI, 14], to fall by the wayside [Luke VIII, 5; Matthew XIII, 4], to wrestle with an angel [Genesis XXXII, 24-25], to appeal to Caesar [Acts XXV, 11], etc. The relevance of phraseological units embraced by this structural-grammatical model is confirmed by their modern contextual use, e.g.:

$<\ldots>$ It was also alleged that he amassed wealth by exploiting his high credit with the Palmyra court, accepting douceurs from citizens wanting favours. Paul's opponents found it easier to agree in synod on his unworthiness for office than to eject him from the episcopal residence. The Palmyra authorities gave them no assistance. But the fall of Palmyra to the Emperor Aurelian (271) re-established Roman power in Syria. If St Paul could appeal to Caesar, so could the bishops opposed to Paul of Samosata. Aurelian ruled that the latter's continued occupation of the bishop's residence was a matter to be decided by the bishop of Rome and his Italian synod. \# Diocletian and the Rise of Constantine \# In the middle decades of the third century, political crises, a drastic trade recession, inflation, civil war, and barbarian invasions almost produced the collapse of the Roman empire. In 257 the Emperor Valerian ordered the harassment of the church. (BNC // The Oxford illustrated history of Christianity. McManners, John (ed.). Oxford: OUP, 1990, pp. ??. 1427 s-units.).

This structural-grammatical model serves as a base for phraseological units with the same structure but with new lexical components, thus allowing numerous lexical variants of the given phraseological units. The lexical variability is primarily characteristic of verbal components of the biblical PUs under study: to trample under foot / to tread under foot [Isaiah XXV, 14], to cry/ declare/ proclaim/ shout from the house-tops [Luke XII, 3], prepositional variability is also inclusive: to proclaim upon the house-tops. The lexical variability of substantive components within the frame of the model is high as well: to rise from the dead / to rise from the grave [John II, XXII; Luke XVI, 31], to go to kingdomcome / to go beyond the veil/ to go to glory / to go to heaven [Ecclesiastes XII, 5]. Compare the contexts:

(a) A strapping lad like Cliffy Benton to be smashed up and put out of his life and all the parsons can do about it is stuff religion down your throat and try to make your believe Cliffy's gone to glory: 'God knows best.' (K.S. Prichard. Golden Miles).

(b) Whether or not one feels that, by modern standards, Mrs Sherwood's attitude was a healthy one, the fact remains that, despite the loss of a second child in India, she and her husband were able to return to England with their faith unimpaired, and settled down to live useful and active lives. One of the hazards of the sudden death of infants was that they might be carried off before they had been baptised. The doctrine of original sin and baptismal regeneration meant that an unbaptised infant could not go to heaven. Devout parents thus lost their greatest consolation, that of being eventually reunited with their dead child. In the tightly-knit Victorian family, this prospect of permanent separation was more terrible than death itself. At one time, the so-called baptismal syringe was actually inserted into the womb in cases in which prolonged and possibly fatal labour was anticipated. Mrs Sherwood records an instance in which her brother, who was a clergyman, was summoned to baptise an infant whose life was in danger. 'My brother, thought $<\ldots>$ '. (BNC // The masks of death. Cecil, Robert. Lewes, East Sussex: The Book Guild Ltd, 1991, pp. ??. 1312 s-units.).

The (a) and (b) contexts above show the identity of the variants, both being used in the meaning of 'to die'.

Model 3. V + $\boldsymbol{\theta}$ 's + N

It is a three-component non-prepositional structural-grammatical model with the constant-variant-changeable dependence of components: to search one's heart [Romans VIII, 27], to harden one's heart [Exodus VII, 3], to give one's life [John XV, 13], to pitch one's tent [Genesis XII, 8], etc. The relevance of none-variable phraseological unitsthose with constant-variant-changeable dependence of components-embraced by this structural-grammatical model is confirmed by their modern contextual use, e.g.:

I will write to you from wherever we pitch our tent, and, of course, I shall write to Cecily. (J. Galsworthy. The Dark Flower.).

The given PU model may appear as a result of a quantitative change in the component structure of the phraseological unit: to sell one's birthright for a mess of pottage [Genesis XXV, 29-34] > to sell one's birthright, etc.

This type of model easily produces verbal as well as structural variants: to bear/ carry one's cross [Matthew X, 38], to eat/ swallow/ take back one's words [Jeremiah XV, 16], to strengthen somebody's hands / strengthen the hand of somebody [Samuel XXIII, 16], etc.

(a) My hand would be immeasurably strengthened if we could get Henderson back here. He's really our only impartial witness, you know. (F. Knebel and Ch. Bailey. Seven Days in May. Friday Morning.).

(b) Badoglio, wanted by Ethiopia for ordering the use of poison gas and the bombing of Red Cross hospitals after Italy invaded the country in 1936. The FO noted that he had provided 'valuable assistance' to the allied cause as Prime Minister after Italy's surrender in 1943, and that it would be 'inopportune' to hand him over to the Ethiopians. Most of the 800 named by the commission were wanted by Yugoslavia, and the FO secretly acknowledged that it had an excellent case. Churchill, in particular, was concerned not to weaken the Italian Government and strengthen the hand of Communists who had dominated the wartime resistance movement. 'The longer we can procrastinate, the better for 
all concerned,' wrote an FO official in 1946. In 1947 Britain and the US said the matter should be left to the Italian courts. One of those most wanted by Yugoslavia but allowed to go unpunished was General Mario Roatta. (BNC // [Guardian, elect. edn. of 19891108]. Home material, pp. ??. 1197 s-units.).

Both the contexts above, illustrating the PU variants - strengthen somebody's hands / strengthen the hand of somebody-demonstrate their identical meaning 'give more power to do something or act against somebody/ something'.

Model 4. $\mathrm{V}+$ Prep $+\boldsymbol{\theta}$ 's $+\mathbf{N}$

It is a three-component prepositional structural-grammatical model with the constant/-variant-/changeable dependence of components: to stink in somebody's nostrils [Amos IV, 10], to spring from somebody's loins [Genesis $\mathrm{XXXV}, 2]$, to lie at somebody's door [Genesis IV, 10], etc. The biblical idioms obtaining this structural-grammatical model have a tendency to acquire morphological-syntactical variants (Kunin 1972: 184-185), e.g. correspondingly: to stink in the nostrils of somebody, to spring from the loins of somebody, to lie at the door of somebody. Let us compare the contextual illustrations:

(a) $<\ldots>$ if they will murder me... let my sins as well as my blood lie at their door. (W. Scott. The Heart of MidLothian.).

(b) Admittedly the vicious cycle of police militarization and public alienation is seen to be kicked into play by the economic crumbling of the inner city, but thereafter the weight of the explanation is placed on inadequate (or overheavy) policing. As will be indicated below, I do not feel that much (if any) of the explanation can lie at the door of the police station. More plausible is the analysis developed in Dahrendorf's Hamlyn Lectures on 'law and order' (Dahrendorf, 1985, 1987). In this the main structural precondition of growing crime is seen as the growth of an underclass. The social prerequisite of the long trend in the late nineteenth and early twentieth centuries towards lower crime and disorder, and greater police acceptance, was the historical process of working-class incorporation. (Pimlott, Ben and MacGregor, Susanne. Oxford: OUP, 1991, pp. 1-92. 1150 s-units.).

If you compare the contexts, you will see that the meanings of the analyzed PU morphological-syntactical variants are identical and both may be defined as 'to indicate to somebody's responsibility for his/ her doing wrong'.

Model 5. $\mathbf{V}+(\mathbf{d})+\mathbf{N}+$ Prep $+(\mathbf{d})+\mathbf{N}$

It is a three-component prepositional structural-grammatical model with the constant/-variant/ dependence of components: to cast pearls before swine [Matthew VII, 6], to eat the bread of idleness [Proverbs XXXI, 27], to grind the face of the poor [Isaiah III, 15], to beat swords into ploughshares [Isaiah II, 4], to make bricks without straw [Exodus V], e.g.:

He quotes them extensively nevertheless, together with other equally suspect evidence, because otherwise he would have no straw with which to make his bricks. (A. P. Cowie, et al. 2000).

Though substantive components may undergo variability here: to eat the bread of affliction [Deuteronomy XVI, 3] / to eat the bread of sorrows / to eat the bread of humiliation [Psalms CXXVII, 2], lexical variants are still more characteristic of the verbal component of the idiom: to divide the sheep from the goats / to separate the sheep from the goats [Matthew XXV, 32-33], to separate the wheat from the chaff / to sort out the wheat from the chaff [Matthew III, 12]. See the illustrating contexts:

(a) $<\ldots>$ the applicant has to obtain the court's leave at the outset. This gives the courts a useful power to separate the wheat from the chaff among the pending cases. So long as there is a full right of appeal against a refusal of leave-a right which the present Government sought, at one stage, to abolish-this handicap is acceptable, even though it places public authorities in a more privileged position than the ordinary litigant. A less acceptable handicap is the special rule that the application for judicial review must normally be made within only three months from the decision complained of. It is in the public interest for challenges to the $<\ldots>$. (BNC // [Independent, elect. edn. of 19891006]. Law material, pp. ??. 150 s-units.).

(b) $<\ldots>$ a pinball freak's dream come true. As with video cabinets, it's my belief that Williams are the technical masters of the steel ball. There are thrills, spills and points aplenty in hurricane. Are you a pinball wizard? \# ZZAP! 64 \#' LOVE IS THE SLUG' \# FlashBack! \# Money for old rope, or bundles of brilliant bargains? \# The mail bag has been bulging with budget priced rereleases of old C64 games again this month and, as ever you can rely on us to sort out the wheat from the chaff, the men from the boys and totally t'riffic from the turkeys! \# SKATE WARS \# The Hit Squad, 3.99 Ice skating, what a load of old tosh, eh? I mean, you slide around half the time on your bottom (just like Joanne Conway!). I can hardly stand up at the best of times - which isn't surprising when the only ice I'm interested in is in my Scotch on the rocks! And I couldn't tell a triple Axel from $a<\ldots>$. (BNC // Zzap 64! Ludlow, Shropshire: Newspaper Pub, 1992, pp. 4-68. 2399 s-units.).

The analysis of the contextual usage makes the meanings of the verbal variants - to separate the wheat from the chaff / to sort out the wheat from the chaff-explicit: in fact they are identical and both serve to denote 'to separate what is valuable from what is worthless'.

Quantitative-reduced variants (Fedulenkova 2016: 57) are also observed within the frames of the model: to touch the ark of the covenant $>$ to touch the ark [Samuel VI, 6], etc.

Model 6. $\mathbf{V}+(\mathbf{d})+\mathbf{N}+$ Prep $+\boldsymbol{\theta}$

It is a three-component prepositional structural-grammatical model with the constant/-variant/-changeable dependence of components: to dig a pit for somebody [Ecclesiastes X, 8], to break bread with somebody [Acts XX, 7]. The relevance of the phraseological units embraced by this structural-grammatical model is confirmed by their modern contextual use, e.g.: 
$<\ldots>$ give as good as he got. He waited for the laughter to die down and then, ignoring Mickey Aronson, he leaned his head out of the window, gave his gravelly laugh and confided to the other men: 'A bigger ignoramus I never met; he doesn't even know that ships and cars are always female.' The exchange put him in excellent mood for his breakfast. Rabbi Moishe, too, was looking forward to his Sunday breakfast. For him it held a special appeal; the one day of the week he could break bread with his family and not have to feel that they were only loaned to him for the while - his son Joshua had no business to go to, his grandson Jacob no college lectures. The Sabbath meals, of course, were family occasions also, but they were invested with the day's solemnity and holiness. If the Sabbath was a day of rest from labour, Sunday, Rabbi Moishe sometimes thought - but it was not a thought he voiced for fear of being misunderstoodwas a day <...>. (BNC // A land not theirs. Marcus, David. Poolbeg P, 1993, pp. 7-112. 2231 s-units.).

Within the model the lexical variability is characteristic of substantive, prepositional and changeable components, the latter are symbolized by the Greek letter $\theta$ : to open the door/ doors to something [Corinthians XV, 9], to be a law into/ unto oneself [Romans II, 14], to make light of somebody/ something [Matthew XXII, 5], etc.

Model 7. $\mathbf{V}+\boldsymbol{\theta}+$ Prep $+(\mathbf{d})+\mathbf{N}$

It is a three-component prepositional structural-grammatical model with the constant/-variant/-changeable dependence of components: to build something on a rock [Matthew VII, 24], to build something on the sand [Matthew VII, 26], to pluck/ take something by the beard [I Samuel XVII, 35], to take/ lay something to heart [Ecclesiastes VII, 2], etc.

The relevance of the phraseological units embraced by this structural-grammatical model is confirmed by their modern contextual use, e.g.:

$<\ldots>$ but defaulting Abbey Lairds no longer occupied the area where Thomas de Quincey knew he was safe from his creditors and Walter Scott seriously thought of doing the same thing. One way of never having to become a hostage to the tolerance of a credit-giving retailer, the patience of a money-lender, the goodwill of a pawnbroker, to surrender to the sorrow of exile or the safety of sanctuary, was to emulate Thomas Creevey of whom Charles Greville wrote in his journal in 1829: Few could be expected to assume that eccentricity. More would be likely to take to heart Samuel Smiles's advice to look their affairs in the face. It was their bounden duty, he said, to keep an account of their incomings and outgoings in money matters. Half a century later the top-hatted, side-whiskered Stingy Uncle in Punch was giving the same advice. 'Pay as you go, my boy! Pay as you go!' he told his nephew. No money to pay with? Then don't go. There had always been that choice, and it was as difficult <... . (BNC // The worst poverty: a history of debt and debtors. Barty-King, Hugh. Gloucester: Alan Sutton Pub. Ltd, 1991, pp. 85-203. 1451 s-units.).

This structural model proves to cause developing of the verbal variability in the phraseological units: to pull/ snatch somebody/ something out of the fire [Jude I, 23], to hide/ keep/ lay/ wrap up something in a napkin [Luke XX, 7], to bring/ call/ put something in/into question [Acts XIX, 40], etc. Compare the contextual use of the given phraseological variants:

(a) $<\ldots>$ then why should Muslims not elevate the obligation to defend Muhammad's honour above the liberal desire to prostitute his reputation? Is Mr Torode's liberalism any less an absolute ideological position than the Islamic fundamentalism of his opponents? Such attitudes create a deadlock. The opponents, then, regrettably, tend to move into the sphere of physical power. Muslims soberly recognise that, in a world addicted to the logic of coercion, it is, sadly, sometimes necessary to be militant in the defence of one's persuasion. In the end, John Torode's attitudes bring into question the very purpose of law. Most liberals have thought that we, unfortunately, needed the firm yoke of the law to ensure that the interests of weaker individuals and groups were not substantially harmed by the irresponsible attitudes and actions of the more powerful. If the new liberals have their way, the law can not be credited even with such a modest achievement. The final irony is that the kind of liberalism John Torode wants is itself illiberal. There can be nothing but hubris in a position <...>. (BNC // [Independent, elect. edn. of 19891010]. Editorial material, pp. ??. 371 sunits.).

(b) The CEGB disclosed the escalation in nuclear costs as it announced that operating profits are 603 million lower than expected at 355 million. The return on assets works out at 1.8 per cent compared with a 3.75 per cent target set by the Government. Most of the nuclear increases result from cost increases by British Nuclear Fuels, the reprocessing body which supplies both the civil and military atomic programme. After revising its own nuclear liability, BNFL has passed these on to the electricity industry in the form of new fixed price contracts. The findings again call into question the Government's attempt to privatise nuclear power despite constant warnings over the costs The shadow Energy Secretary, Mr Frank Dobson, claimed yesterday that the CEGB's accounts had been 'massaged and adjusted to suit the Government's privatisation policies'. They owed a lot more to artistic interpretation than to technical merit, he said. Analysts at Smith New Court, the City stockbroking firm, said yesterday: 'The costs are much higher than we thought. They are a result of the auditors saying <... . (BNC // [Guardian, elect. edn. of 19891222]. Home material, pp. ??. 1021 s-units.).

(c) the consequence of heterosexual ardour. To shift, as I have done in this consideration of Love's Cure, from the transvestite to certain wider issues of desire, the 'nature' of masculinity, sexual jealousy, and the homoerotic, is only to follow one trajectory of transvestism itself in this period: in appropriating, inverting, and substituting for masculinity, the female transvestite inevitably put masculinity itself-and sexual difference more generally-under scrutiny. Further, in the attempted containment of transvestism (Love's Cure) masculinity and sexual difference are put in question in a very specific way: in the containment of one hostile knowledge another is inadvertently produced; suppression of an (in) subordinate deviance discloses other, equally disturbing deviations at the heart of the dominant; erotic deviations whose repression is a condition of domination in one of its most important forms: homosocial male bonding. Finally, 
the transvestite challenge to masculinity and sexual difference works in terms of transgressive inversion and reinscription, not of transcendence, or the recovery of authentic selfhood. (BNC // Sexual dissidence. Dollimore, Jonathan. Oxford: Clarendon Press, 1991, pp. ??. 1770 s-units.).

The contextual use of the PU variants testifies to the fact that this type of variability does not destruct the identity of the phraseological unit, i.e. the phrase retains its basic meaning which runs as follows 'to cause something to be evaluated'.

As to substantive variants in the phraseological units of Model 7, they are a rare occasion within the model: to chastise somebody with scorpions/ chastise somebody with whips [I Kings XII, 11].

RESUILTS AND CONLISION. To sum it up, we come to the conclusion that verbal phraseological units of biblical origin are widely spread in Modern English. This fact can be explained by the simplicity and naturalness of their grammatical structure and by the fact that they are intensively used in everyday speech of native speakers. The presence of prepositional components in the phraseological units of the analyzed models demonstrates analytical character and flexibility of the phraseological units under study. The availability of alternative components and the abundance of different types of variants testifies to the fact that English phraseological units of biblical origin present a certain subclass of phraseology, and being units with either full or partial semantic transference of components, their meaning is often motivated. Structural variability does not destruct the meaning of the phraseological units under study.

\section{REFERENCES}

Adamia, Zoia (2019) Comparative analysis of biblical phraseological units (in the Russian, English and Georgian languages). International Scientific-Pedagogical Organization of Philologists “ WEST-EAST" (ISPOP). Scientific Journal WEST-EAST. Vol 1 N1. (March), pp. 20-26. DOI: https://doi.org/10.33739/2587-5434-2019-20-26.

Cowie, A.P., Mackin R. and I.R. McCaig. (2000) Oxford Dictionary of Current Idiomatic English. Vol. 2: Oxford Dictionary of English Idioms. Oxford: Oxford University Press.

Fedulenkova, T. (2003) A new approach to the clipping of communicative phraseological units // Ranam: recherches anglaises et nord-américaines: European Society for the Study of English: ESSE 6 - Strasbourg 2002 / Ed. P. Frath \& M. Rissanen. Strasbourg: Université Marc Bloch. Vol. 36, 11-22.

Fedulenkova, T.N. (2006) Odnomernye i dvumernye modeli $v$ angliyskoy, nemetskoy i shvedskoy frazeologii: monografgia [Onedimensional and two-dimensional models in the English, German and Swedish phraseology: monograph]. Arkhangelsk: Pmorskiy universitet.

Fedulenkova, T.N. (2016) Lektsii po angliyskoy frazeologii bibleyskogo proishozdenia [Lectures on English Phraseology of Biblical Origin]. Moscow: Izdat. Dom Akademii Estestvoznania.

Fernando, Ch. (1996) Idioms and Idiomaticity. Oxford, New York: Oxford University Press.

Komarova, Z.I. (2013) Metodologiya, metod, metodika i tehnologiya nauchnyh issledovaniy v lingvistike [Methodology, method, technique and technology of scientific research in linguistics], Moscow: FLINTA, Nauka.

Kunin, A.V. (1970) Anglijskaya frazeologiya. Teoreticheskiy kurs [English phraseology. Theoretical course]. Moscow: Vysšaja Škola.

Kunin A.V. (1972) Frazeologiya sovremennogo anglijskogo jazyka : opyt sistematizirovannogo opisania [Phraseology of modern English: experience of the systematized description]. Moscow: Vyssh. shk. [Online]. Available from: http://search.rsl.ru/ru/record/01004149688 [Accessed: 28.07.2019].

Kunin A.V. (1996) Kurs frazeologii sovremennogo anglijskogo jazyka [A course on phraseology of the Modern English language]. Moscow: Vysšaja Škola; Dubna: Feniks.

Mokienko V.M. (1976) Protivorechiya frazeologii i ee dinamika: Avtoref. dis. ... d-ra filol. nauk [Contradictions of phraseology and its dynamics: Thesis of Habilitation Doctoral Dissertation]. Leningrad.

The Holy Bible (2001): The old and New Testament: Authorized King James Version. Iowa: World Bible Publishers.

\section{For citation:}

Fedulenkova, T. \& Adamia, Z. (2019) SEVEN FREQUENT MODELS IN BIBLICAL PHRASEOLOGY OF MODERN ENGLISH. International Scientific-Pedagogical Organization of Philologists “ WEST-EAST ” (ISPOP). Scientific Journal WEST-EAST. Vol 1/1 N1 (October, 2019). p.p. 17-23. doi:

\section{Для цитирования:}

ФедУЛенкова, Т.Н., АДамия, З.К. (2019) СЕМЬ РАСПРОСТРАНЕННЫХ МОДЕЛЕЙ В БИБЛЕЙСКОЙ ФРАЗЕОЛОГИИ СОВРЕМЕННОГО АНГЛИЙСКОГО ЯЗЫКА // International Scientific-Pedagogical Organization of Philologists "WEST-EAST" (ISPOP). Scientific Journal WEST-EAST. Vol 1/1 N1 (October, 2019). C. 17-23. doi:

Information about the author: Tatiana Fedulenkova - Doctor of Philological Sciences, Professor, Department of Foreign Languages of Professional Communication of the Institute for the Humanities, Vladimir State university named after the Stoletov Brothers. Member of Professorial Assembly of Russian Federation. Member of the Scientific Council on philological sciences of RPB, Correspondent member of RANH (Russia)

e-mail: fedulenkova@list.ru

Сведения об авторе: Татьана Николаевна Федуленкова - доктор филологических на-

ук, профессор, Владимирский государственный университет им. братьев Столетовых.

Член профессорского собрания Российской Федерации, член Научного Совета по фило-

логическим наукам РПС, член-корреспондент РАЕ (Россия)

e-mail: fedulenkova@list.ru 
Information about the author: Zoia Adamia - PhD, prof., Research worker of Institute of Russian Language and Literature at Tskum-Abkhazian Academy of Sciences. Editor-in-Chef of Scientific Journal "WEST-EAST", Deputy Director of the International Scientific-Pedagogical Organization of Philologists "WEST-EAST" (Georgia).

e-mail: a.zoia777@gmail.com

Сведения об авторе: Зоя Адамия - Доктор филологии, проф., Институт русского языка и литературы Цхум-Абхазской академии наук. Главный редактор научного журнала «WEST-EAST». Заместитель директора международной научнопедагогической организации филологов «Запад-Восток» (Грузия).

e-mail: a.zoia777@.gmail.com

DOI:

\title{
ZOONYM WOLF IN PHRASEOLOGY AND PARAMIOLOGY: CULTURAL CONNOTATIONS (IN RUSSIAN, UKRAINIAN, CHECHEN AND ENGLISH)
}

\author{
Luiza N. Gishkaeva \\ PhD in Philology, Associate professor \\ RUDN University \\ (Moscow, Russia) \\ e-mail: adv88-02@mail.ru \\ Olga V. Lomakina \\ Doctor of Philological Sciences, \\ Professor, St. Tikhon's Orthodox University, \\ Peoples' Friendship University of Russia \\ (Moskow, Russia) \\ e-mail: rusoturisto07@mail.ru
}

The publication has been prepared with the support of the RUDN University Program 5-100

\begin{abstract}
The article is devoted to the description of connotations of a zoonym wolf in unrelated and related languages - in Russian, Ukrainian, Chechen and English. We study a zoonym (animalism) as a culture-specific component of phraseology and paramiology, which presents the universal and the national in the language and ads to the knowledge of a national world view of a specific nation. The article gives semantic peculiarities of phraseological units and paroemias, which include an animalism wolf: describing the ways of wolf and the features of the animal, its appearance and the description of the parts of its body, its habitat. It is proved in the article that even in different unrelated languages the lexical unit wolf has negative connotations. There are only few paroemias containing positive connotations of a zoonym wolf.
\end{abstract}

Key words: zoonyms, phraseological units, paroemia, value, zoonym wolf

\section{ЗООНИМ ВОЛК ВО ФРАЗЕОЛОГИИ И ПАРЕМИОЛОГИИ: КУЛЬТУРНЫЕ КОННОТАЦИИ (НА МАТЕРИАЛЕ РУССКОГО, УКРАИНСКОГО, ЧЕЧЕНСКОГО И АНГЛИЙСКОГО ЯЗЫКОВ)}

\author{
Луиза Нахидовна Гишкаева \\ Кандидат филологических наук, доцент \\ Российский университет дружбы народов \\ (Москва, Россия) \\ e-mail: adv88-02@mail.ru \\ Ольга Валентиновна Ломакина \\ Доктор филологических наук, профессор \\ Православный Свято-Тихоновский гуманитарный университет, \\ Российский университет дружбы народов \\ (Москва, Россия) \\ e-mail: rusoturisto07@mail.ru
}

Публикация подготовлена при поддержке Программы РУДН "5-100".

Аннотация. Статья посвящена описанию коннотаций зоонима волк в неродственных и родственных языках - русском, украинском, чеченском и английском. Зооним (анимализм) рассматривается нами как культурно маркированный компонент 